\title{
感圧スイッチを用いた被乗駕行動測定装置による 放牧牛の授精適期の推定
}

\author{
土肥宏志・山田明央* ・圓通茂喜 ${ }^{1)} \cdot$ 住川隆行 ${ }^{* *}$ \\ 農林水産省中国農業試験場，大田市 694 \\ *農林水産省草地試験場, 栃木県西那須野町 329-27 \\ **岩手県地域農業改良普及センター久慈, 久意宋 028
}

(1997. 3. 18 受付)

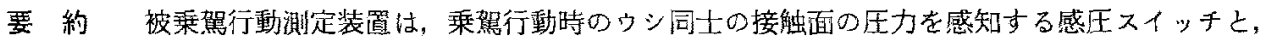
そのスイッチに圧力が加わった時刻上，除加れた時刻を記録する装置で構成されている，被乗嘿行陲测 定装置を装着したウシに他のウシが乗鴐した際に，その時刻之被乗㚙行動の持続時間が記録される。こ の装置により発情の時間帯が特定でき，また授精適期を推定するための有用な情報か得られるから゙うか 検討した，実験 1 では，繰り返しを含めて7頭の黒毛和種雌牛において，被乗駕行動測定装置により得 られた巽駕許容を示していると推定される 3 秒以上の持続時間を示す被乗駕行動の頻度分布から，発情 の時間帯が判定できることを示した，実験 2 では，50頭からなる繁殖特群内で，発情を誘起した 6 頭の ウシにこの装置を装着し，1日に2回の定期的な牛群の肉眼観察により，この6頭のウシの授精適期を 推定し，人工授精を行った，その結果，测定装置の記録より判定された発情の開始と終了時刻加ら推定 された授精適期の範囲队で, 人工授精された 4 頭のウシは受胎した。 また, 授精適期以外で人工授精さ れた 1 頭のウシは受胎しなかった。これらの結果は，この感圧スイッチの测定記録をテレメーター装置 などにより，実時問で得ることができれば，適期に人工授精が可能なこ上を示唆している.
\end{abstract}

日畜会報, $68(8): 774-779,1997$

放牧心打引る繁殖牛の発情の発見は，授精適期を推定 し人工授精を行うたるの基本技術である。のシの発情の 時間带は，乗駕許容行動の開始から終了までの時間であ るとし, 発情の開始や終了の時間を基準として, 非莭時 期と授精適期を推定する多くの研究が報告されてい $3^{3,4,11,12)}$

現在のところ被乗嫼行動を指標とした発情発見技術と しては，被垂駕行動を含めた外部徴侯の肉眼による定期 的な観察，ヒート・マウントデイテクター法，テールペ イント法がある99. しかし，ヒート・マウントデイテク ター佉とテールペイント法では，発情時の乗嘿許容行動 と発情時以外の被乗鴐行動を区別するのは，因難なこと が多い．また，これらの2種類のいずれの力法も，連続 的に被垂鴐行動を測定できないため，授精適期を推定す るために重要な情報である発情の開始と終了の時間を把 握できない，肉眼による観察では乗駕評容の行動の開始

\footnotetext{
1) 1997 年 3 月 16 日逝去
}

日畜会報，68（8）：774-779 り定期的化観察する必要がある。実際, Lauderdale ら は1日に2回あるいは3回の定期的な牛群の観察に比 べ，連続的に観察するこよにより，発情の発兒率は高く なると報告している。しかし，日常の繁殖牛の管理の中 で, 短時間間隔で長時間にわたり定期的に牛群の観察を 行うことは大変に困難である.

前報りにおいて感压スイッチを用い，ウシが他のウシ に乗駕された時刻之乗鴐されている持続時間を正確に測 定するため，スイッチの感度とウシへの装着部位の選定 を行った、今回の研究では, 前報で選定された感区ス イッチを実際の放牧地でウシに装着し，乗駕された時刻 とその持続時間の测定記録から，踓牛の発情の開始上終 了が判定できることを示した．また，発情牛の授精適期 を推定する際に,この装置の有效性を検討した。 


\section{材料および方法}

\section{被乗駕行動測定装漹}

本実験で用いた被乗嘿行動測定装置は, 著者らの前 報りに詳細に報告されている。以下に，その装置につい ての概路を述べる、この装置は, ウシが他のウシに乗嘿 された時のウシ同士の接触面に生じる氏力を感知する感 王スイッチと, その時刻を記録するパルス信号入力器で 構成されている。スイッチは，接着剤とビニールテープ により革製の牛具に固定し，パルス信号入力器は牛具の ポケットに格納した．本奏験では，前報りで検討した結 果, もっと6正確に被莱駕行動を測定できた，動作玨力

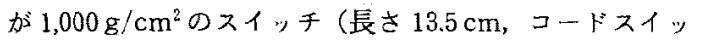
チ,ブリジストン社，東京）をウシの腰解を結ぶ線から 後方の背線上に溹着した（図 1)。このスイッチと入力器 を装着したウシに他のウシが駕ずると，嘿したウシ がスイッチに接螌し on の信号が発生する，次に，この 乗駕行動が終了した時にスイッチへの圧力が除かれ， off の信号が発生する. その on $上$ off の発生特刻は，ハ ルス信号入力器により年・月・日・時・分・秒まで記録 される。しかし，一旦 onまたは off の信号が入力された 時刻加ら1秒の間, 感压スイッチで発生する on と off の信号はパルス入力器に記録されない，そのため，1秒 以内の持続時間を持つ被乗駕行動向，1秒間の持続時間 を持つ被垂嘿行動として部録される。

前報”の試験の中で，肉眼による観察ではウシが乗駕

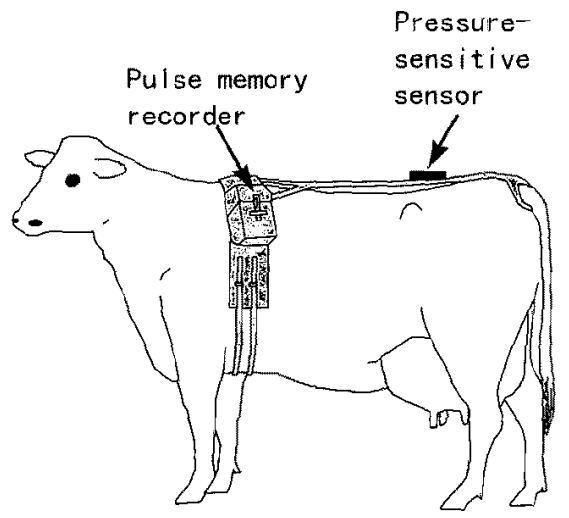

Fig. 1. The switch and recorder unit on the harness worn by cattle

A $13.5-\mathrm{cm}$ switch that operated with a pressure of $1,000 \mathrm{~g} / \mathrm{cm}^{2}$ was fitted on the line combining the highest points of the left and right hip bones toward the tail.
許容の幽態です，スイッチにかかる加力は変化している ため、1回の乗嘿䛨容行動中に off 之onの信号が繰り返 し記録されるこしが示された，そこで， off の信号か記 録されてから3秒以内に on の信号が記録されたとき は，1回の被筧行偊の㻌中で，ウシ同士の接触面にお ける王力の変北により生じた信号と見なし，1回の乗然 許容行動が継続しているすのとした，本奏験では 3 秒以 上の持続時間を示す被乗嫼行動を乗㚙許容行動上仮定 L，以下の実験 1 と 2 で被乗嘿測定装置により被垂嫼行 動を測定したウンについて，発情の時問帯の半定を行っ t心.

\section{放牧地における被乗嘿行動の測定}

実験 1: 墨毛和種の雃 6 頭 (No. $1237 \mathrm{~kg}$, No. 2239 $\mathrm{kg}$, No. $3273 \mathrm{~kg}$, No. $4274 \mathrm{~kg}$, No. $5280 \mathrm{~kg}$, No. 6289 $\mathrm{kg}$, 全て未経産) と去勢雄牛 2 頭 $(205 \mathrm{~kg}, 315 \mathrm{~kg}$ ) 存 一群として放牧した。放牧地は草地試駼場のオーチャー ドグラス主体の草地で，面積は約 1 ha であった，6頭の 䧳牛の中で，実験開始前の日常の観察で得られた発情周 期と直腸検查の結果から，発情誘起が可能な1頭加ら2 頭のウシにプロスタグランジン $\mathrm{F}_{2 \alpha}$ 安投与した，投与し

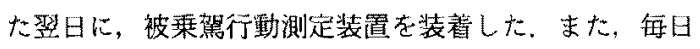
10 時に直腸㮩查を行い，排切の確認を行った。No. 1 の ウシについては，同様な実験を2回絽り返した。

実験 2 : 草地試験場の50頭からなる黒毛和種の繁殖 牛群の 6 頭 (No. $7446 \mathrm{~kg} 4$ 痖, No.8 $387 \mathrm{~kg} 1$ 麾, No. $9394 \mathrm{~kg} 1$ 産, No. $10407 \mathrm{~kg} 7$ 産, No. $11407 \mathrm{~kg} 7$ 産, No. $12369 \mathrm{~kg}$ 末経産)にプロスタグランジン F 20 在投与 し，発情を誘起した，プロスタグランジン $\mathrm{F}_{2 \alpha}$ を投与し たウシには，被葉駕行動测定装置を装着した。またこ の牛群に対しては，ほ践前 9 時と午後 4 時の 2 回の定 期的な牛群の観察と随時観察老行い，この6頭の授精浐 期と推定される時期に人工授精を行った。

\section{結果および考察}

実験 1 で得引れた結果の中から，被乗駕行動測定装置 を3.5日間装着したウシについて，パルス信号入力器に 入力された被乗駕行動の回数を 1 時閒ごとに合計した結 果と，3秒以上持続した乗鴐許容の状態と推定される被 乘駕行動の回数を1時間ごとに合計した結果を図2（ウ シNo.1), 図3(ウシNo.2) に示した。図2によれば,

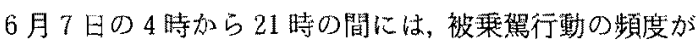
高い状態が継続しており，特に，乗罍許容を示している 上推定される 3 秒以上の持続時間表示被乗㚙行動が高 頻度で記録されていたままた，6月8日の10時の直腸検 查により，排卵が確認された。てこで，6月7日の4 時か 
土肥・山田・圆通・住川

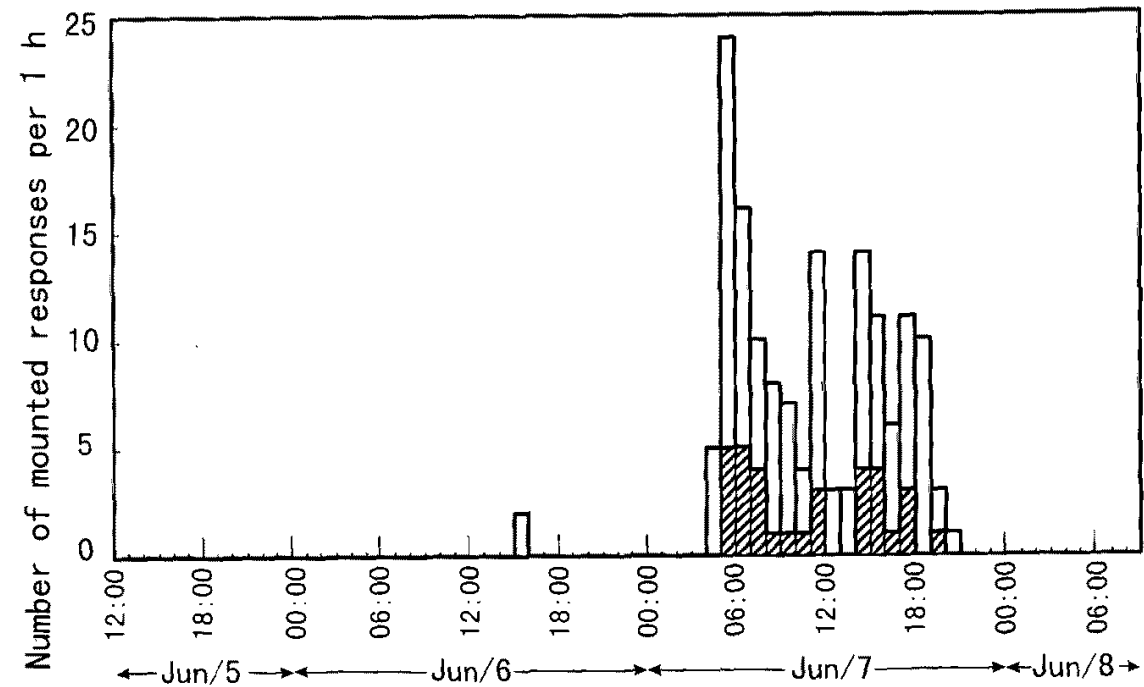

Fig. 2. Changes in mounted responses of No. 1 heifer

The activities were recorded with the device shown in Fig. 1. ( $\square$ ) indicates the number of mounted responses per $1 \mathrm{~h}$, and (the number of standing behaviors to be mounted for three seconds or more per $1 \mathrm{~h}$.

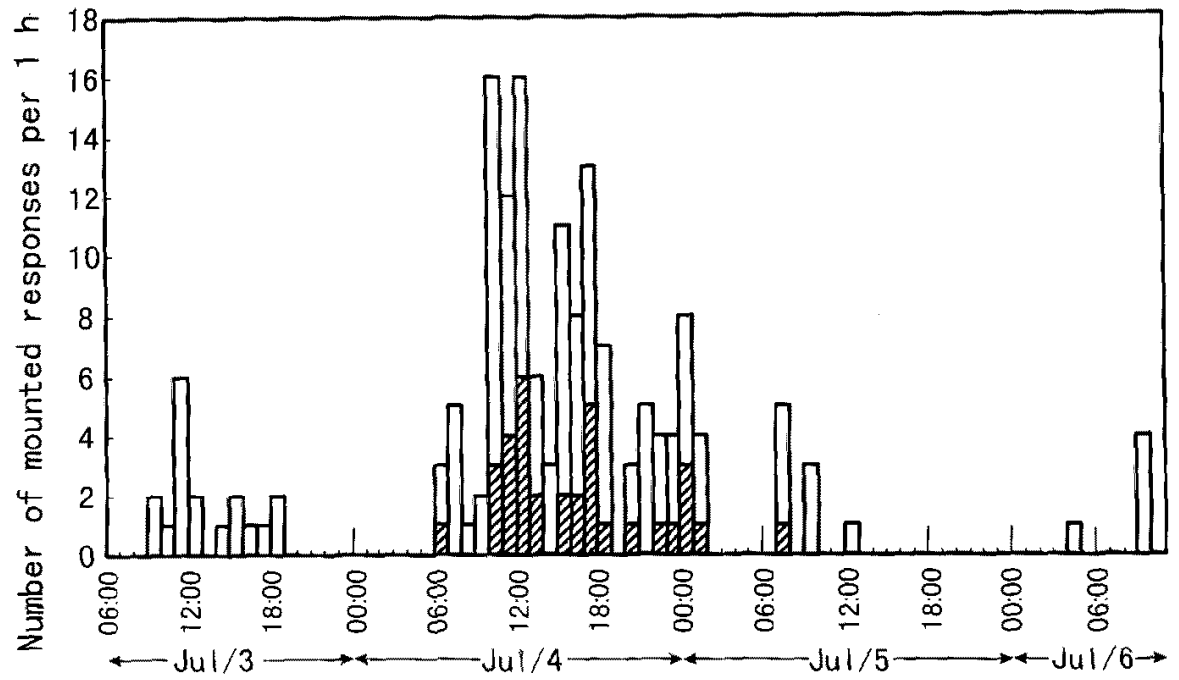

Fig. 3. Changes in mounted responses of No. 2 heifer

The activities were recorded with the device shown in Fig. 1. ( $\square$ ) indicates the number of mounted responses per $1 \mathrm{~h}$, and $(\mathbb{A})$ the number of standing behaviors to be mounted for three seconds or more per $1 \mathrm{~h}$.

ら21時の間が発情の時間帯である之判定できた，6月6 日の 15 時 16 時の間に, 2 回の被乘鴐行動が記録され ていた。しかし，その前後に被乗駕行動は記録されてお
らず，また，3秒以上持続した乗㚙許容行動も記録され ていないため,これは発情時の被乗鴐行動ではないむの と判定した。 


\section{被乗駕行動記録によるウシの授精適期の推定}

図3に括いて，被乗駕回数からだけみると，7月4日 の6時から5日の2 時までの時間帯以外にも，7月3日 の9時加畐7月3日の19時の間に被乗嘿回数の多い時 間带が記録されており，これ以外の時刻にも被乗鴙行動 が何回か記録されている。しかし，この記録された被乗 駕行動のうち3秒以上の乗鴐を許容した行動の回数が多 い時間帯は，7月4日の6時加ら5日02時の時間带で ありこの間にNo.20ウシが発情していたことが判定 できた。また，このウシ络賀許容行動が終〕した 5 日 の10時に行った直腸检查により，排即が確認された，奏 験 1 で乘駕测定装置を装着したウシはいずれも3秒以 上乗㚙を許容する行動が，2特間かる27時間上大きなば らつきがあったが，集中的に記録された時間帯が存在し た。 また，7頭中6頭において，3秒以上の被烡嘿行動の 頻度加ら判定した発情終了の当日あるいは翌日の午前 10 時の直腸検查時に，非卵が確認された。これらの結果 により，感圧スイッチを用いた被莱駕測定装䈯により， 発情の時間帯を判定できることが示された，図 2 と図 3

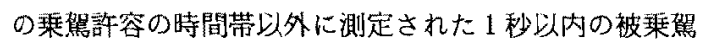
行動は，他の発情したウシによる乗駕行動，あるいは， 测定したりシの発情の前兆である許容堊伴わない被乗驾
行動亡推察された。

表 1 に，実験 1 上実験 2 で用いたウシの発情の平均時 間、発情中の1頭当たり求よび 1 時間当たり被萐唯回数 の平均值を示した。13頭の平均の発情時間は，16.1時間 であった。この值は，平尾・高橋いの9頭のホルスタイ ンを 24 時間観察した結果, 得られた発情の平均時間は 15.3 時間や，60頭のホルスタインの平均発情時間は 14.9 時間であった報告2ほに一致するすのであった。また，本 ルスタインでは発情時間の平均が 10 時間前後と，本実 験の結果に比べかなり短い報告むある3，発情時䦓は，

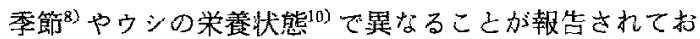
り，発栔時間の差罢の原因と考艺られる。発情時の被 采㽞回数は，平尾・高槁 ${ }^{4}$ が 1 頭当たり153回と報告し ており，本寒驗の結果とほぼ一致していた。発情期当た り 56.3 回という報告尚あるるが，この低い回数の原因 は，被らが日常の搾孚作業により拘束されている時間が 多いウシを観察したためと考えられる。

実験 2 で行った結果を表 2 に示した。亦なわ方，この 被賀测定装犆の湘定結果上り判定された発情時間畒 と，夷際に人工授精が行われた時刻，肪よび，受胎の有 無を赤した。人工授精によって受胎したNo.7とNo.9

Table 1. Duration of estrus and characteristics of the mounted responses of cattle measured using a pressure-sensitive switch during the estrus period ${ }^{\text {a) }}$

\begin{tabular}{lcccc}
$\begin{array}{c}\text { Number of } \\
\text { cows }\end{array}$ & $\begin{array}{c}\text { Duration of estrus } \\
\text { (hours) }\end{array}$ & $\begin{array}{c}\text { Number of mounted } \\
\text { responses per cow } \\
\text { during estrus }\end{array}$ & $\begin{array}{c}\text { Number of mounted } \\
\text { responses per hour } \\
\text { during estrus }\end{array}$ \\
\hline $\begin{array}{l}\text { Experiment 1 } \\
\text { Experiment } 2\end{array}$ & $7^{\mathrm{c})}$ & $15.7 \pm 6.1(7)$ & $128.4 \pm 116.7(7)$ & $8.2 \pm 16.7(109)$ \\
Total & 6 & $16.5 \pm 7.0(6)$ & $143.7 \pm 92.3(6)$ & $8.7 \pm 9.1(98)$ \\
& 13 & $16.1 \pm 6.3(13)$ & $135.5 \pm 102.1(13)$ & $8.6 \pm 13.7(207)$
\end{tabular}

a) Values are means \pm S.D. (n).

b) The duration of estrus was determined based on the distributions of frequency of mounted responses lasting more than three seconds.

c) The experiment was conducted using six heifers, with No. 1 heifer tested twice.

Table 2. Relation between the time of insemination determined by observation of herdsmen and the duration of estrus determined using a pressure-sensitive switch

\begin{tabular}{|c|c|c|c|c|}
\hline Cow number & Inseming & on time & $\begin{array}{c}\text { Duration of estrus determined using the } \\
\text { automatic recorder }\end{array}$ & Conception \\
\hline No. 7 & Jan. $/ 19$ & $16: 00$ & $\operatorname{Jan} . / 19,11: 00-J a n . / 20,2: 00$ & Pregnant \\
\hline No. 8 & Dec. $/ 14$ & $8: 00$ & Dec. $/ 13,10: 00-\operatorname{Dec}_{v} / 14,3: 00$ & Pregnant \\
\hline No. 9 & Dec. $/ 13$ & $16: 00$ & Dec. $/ 13,10: 00-$ Dec $/ 14,1: 00$ & Pregnant \\
\hline No. 10 & $\operatorname{Jan} . / 10$ & $11: 00$ & $\operatorname{Jan} / 9,16: 00-\operatorname{Jan} / 10,6: 00$ & Pregnant \\
\hline No. 11 & Jan. $/ 11$ & $10: 30$ & Jan./ 8, 13:00-Jan./ 9,16:00 & Non-Pregnant \\
\hline No. 12 & \multicolumn{2}{|c|}{ not inseminated } & Jan./26, $17: 00$-Jan./26, $23: 00$ & Non-Pregnant \\
\hline
\end{tabular}


のウシは，発情開始から6時間後，No.8 上 No. 10 のウ シは発情終了後から5時閒で，人工授精を行っており， この 4 頭は，妊娠していることが後に確認された．No. 11 のウシは, 測定装置の結果加ら発情終了後から約 18 時 30 分後に人工授精を行っており，大きく授精適期加 ら外れていることが明らかとなった。 No.12 好発情時間 が非常に短く，また，その期間が 17 時から 23 時まで之 観察者のいない時間帯であったため発情を見逃し，人工 授精注行わなかった，発情の開始と終了の時刻之人工授 精の適期との関係に関する報告は多数古る。平尾・高 橋はは，発情終了前 5 時間と終了後 5 時間の時間査で受 胎率が良い之報告している。 また，人工授精の適期は発 情開始後 7 から 12 時間後3)，あるいは，発情開始後 6 時 間から発情終了後 6 時間の間之報告されている ${ }^{6)}$.

今回の奏験では，被乗駕測定装置に記録された被乗駕 行動の時刻とその持続時間は，人工授精後にウシから装 置を取り外し，人工授精の時刻が授精適期に行われてい るか検討した。また，推定された授精適期と受胎の有無 の関係を検討した，表 2 の結果は, 感圧スイッチにより 测定された被乗㚙時刻とその持続時間を, 実時間で得る ことができれば，適期に人工授精が可能なことを示唆し ている.

\section{文献}

1) Dohi H, Yamada A, Tsuda S, Sumikawa T, Entsu S. Technical Note: A pressure-sensitive sensor for measuring the characteristics of standing mounts of cattle. J. Anim. Sci., 71 : 369-372. 1993.
2) Esslemont RJ, Bryant MJ. Oestrous behaviour in a herd of dairy cows. Vet. Rec., $99 ; 472-475$. 1976.

3) Hall JG, Branton C, Stone EJ. Estrus, estrous cycles, ovulation time, time of service, and fertility of dairy cattle in Louisiana. J. Dairy Sci. 42: 1086-1093. 1959.

4）平尾和義・高橋 战. 牛の集団飼育における発情 牛の行動之授精適期. 畜産の研究, $28: 1310-$ 1314. 1974.

5) Hurnik JF, King GJ, Robertson HA. Estrous and related behaviour in postpartum Holstein cows. Appl. Anim. Ethol., 2: 55-68. 1975.

6）假屋琴由. 新編蓄産大事典. 6. 繁殖の項執筆.（田 先威和夫䜿修）596-611。墓蜸堂. 東京. 1996.

7) Lauderdale JW. Estrus detection and synchronization of dairy cattle in large herds. J. Dairy Sci., $57:$ 348-354. 1973.

8) Pennington JA, Albright JL, Diekman MA. Sexual activity of Holstein cows: Seasonal effects. J. Dairy Sci., 68 : 3023-3030. 1985.

9) Stevenson JS, Britt JH. Detection of estrus by three method. J. Dairy Sci., 60: 1994-1998. 1977.

10）鈴木 修. 黒毛和種此隹牛の繁殖機能の向上に関す る研究. 家畜繁殖誌, 32:111-117, 1986.

11) Trimberger GW. Breeding efficiency in dairy cattle from artificial insemination at various intervals before and after ovulation. Nebraska Agr. Exp. Sta. Res. Bull., 153 : 3-26. 1948.

12) Wishart DF. Observations on the oestrous cycle of the Friesian heifer. Vet. Rec., 90 : 595597. 1972. 


\title{
Application of an Automatic Recorder on Standing Behaviors of Cattle to Estimate Estrus Period and Optimum Insemination Time
}

\author{
Hiroshi DOHI, Akihisa YAMADA*, \\ Shigeki ENTSU ${ }^{1)}$ and Takayuki SUMIKAWA** \\ Chugoku National Agricultural Experiment Station, Oda-shi 694 \\ * National Grassland Research Institute, Nishinasuno-machi, \\ Tochigi-ken 329-27 \\ ** Iwate Prefecture Kuji Agriculture Extension Center, Kuji-shi 028
}

\begin{abstract}
The automatic recorder for standing behaviors of cattle consisted of a pressure-sensitive switch and a recorder that stored the times of the application and removal of pressure from the switch. When an estrus cattle fitted with the switch to its rump is mounted by cattie, the time and duration of the standing behavior are automatically recorded with a pulse memory recorder. The automatic recorder was examined for its usefulness in detecting the onset and end of estrus, and in estimating the optimum insemination time. In experiment 1 , six heifers, one of which was tested twice, demonstrated that there were periods of frequent mounted responses lasting three seconds or more. These results suggested that the device was useful for determining the period of standing estrus. In experiment 2 , six cows in a group of 50 heads were treated with prostaglandin $F_{2 a}$ and fitted with the device. The group were observed twice per day and the six cows were inseminated by a herdsman at the optimum time which was estimated based on his periodic observations. Four cows were inseminated during the period of the optimum insemination time on the basis of the onset and end of estrus, which were determined using data from the automatic recorder, and all the four were pregnant. One cow that was inseminated beyond the limit of optimum time determined using the device, was not pregnant. These results demonstrated that it was possible to inseminate estrus cattle at the optimum time if real-time data on standing behaviors is obtained through the use of a telemetry system incorporating a pressure--sensitive switch.
\end{abstract}

Anim. Sci. Technol. (Jpn.) 68 (8) : 774-779, 1997

Key words : Estrus cattle, Switch, Behavior, Optimum insemination

\footnotetext{
${ }^{17}$ Dr. S. Entsu, one of the coauthors, was deceased on March 16, 1997.
} 